\title{
Evaluation of the Effect of the Energy of Consciousness Healing Treatment on Physicochemical and Thermal Properties of Pyridoxine Hydrochloride
}

\author{
Alice Branton $^{1}$, Snehasis Jana ${ }^{2, *}$ \\ ${ }^{1}$ Trivedi Global, Inc., Henderson, USA \\ ${ }^{2}$ Trivedi Science Research Laboratory Pvt. Ltd., Bhopal, India
}

Email address:

publication@trivedieffect.com (S. Jana)

*Corresponding author

\section{To cite this article:}

Alice Branton, Snehasis Jana. Evaluation of the Effect of the Energy of Consciousness Healing Treatment on Physicochemical and Thermal Properties of Pyridoxine Hydrochloride. American Journal of Physical Chemistry. Vol. 6, No. 4, 2017, pp. 49-58. doi: 10.11648/j.ajpc.20170604.11

Received: May 20, 2017; Accepted: May 31, 2017; Published: July 12, 2017

\begin{abstract}
Pyridoxine hydrochloride is water-soluble B vitamin widely used for the prevention and treatment of vitamin $\mathrm{B}_{6}$ deficiency and other several diseases. The aim of this study was to explore the effect of The Trivedi Effect ${ }^{\mathbb{B}}$ - Energy of Consciousness Healing Treatment on the physicochemical and thermal properties of pyridoxine hydrochloride using PXRD, PSA, DSC, and TGA/DTG analysis. Pyridoxine hydrochloride was divided into two parts, one part of pyridoxine hydrochloride was considered as control (no Biofield Treatment was provided), while second part received The Trivedi Effect ${ }^{\mathbb{B}}$ - Biofield Energy Healing Treatment remotely by a renowned Biofield Energy Healer, Alice Branton. The PXRD analysis exhibited that the relative intensities and crystallite sizes of the most characteristic diffraction peaks in the Alice's treated pyridoxine hydrochloride were significantly decreased from $1.59 \%$ to $44.47 \%$ and $6.31 \%$ to $28.28 \%$, respectively compared with the control sample. Overall, the average crystallite size of the treated sample was significantly reduced by $5.55 \%$ compared with the control sample. The particle size values at $\mathrm{d}_{10}, \mathrm{~d}_{50}, \mathrm{~d}_{90}$, and $\mathrm{D}(4,3)$ (average mass-volume diameter) in Alice's treated sample were significantly reduced by $13.87 \%, 9.95 \%, 7.87 \%$, and $6.59 \%$, respectively compared to the control sample. The specific surface area of treated sample was significantly increased by $13.67 \%$ compared to the control sample. The DSC analysis revealed that the melting point of the treated sample was lower by $0.20 \%$ with a significant reduction of the latent heat of fusion by $24.52 \%$ compared with the control sample. The TGA analysis revealed that the total weight loss in the treated sample was increased by $1.76 \%$ compared with the control sample. The DTG analysis indicated that the maximum thermal degradation temperature of the treated sample was reduced by $0.88 \%$ compared to the control sample. Overall, the thermal analysis indicated that the thermal stability of the treated pyridoxine hydrochloride was declined compared to the control sample. Thus, The Trivedi Effect ${ }^{\circledR}$ might lead to the production of a polymorphic form of pyridoxine hydrochloride which would be more soluble, absorbable, have a higher dissolution rate and be more bioavailable compared with the untreated sample. The Biofield Energy Treated pyridoxine hydrochloride would be beneficial in the design of better nutraceutical and pharmaceutical formulations which might provide better therapeutic responses against vitamin $\mathrm{B}_{6}$ deficiency, sideroblastic anemia, cardiovascular disease, diabetes, Alzheimer's disease, pyridoxine-dependency seizures, metabolic disorders, pulmonary tuberculosis, hyperhomocysteinemia, cancer, anxiety, asthma, depression, dysmenorrhea, etc.
\end{abstract}

Keywords: Pyridoxine Hydrochloride, Biofield Energy, The Trivedi Effect ${ }^{\circledR}$, Energy of Consciousness Healing Treatment, PXRD, Particle size, DSC, TGA/DTG

\section{Introduction}

Pyridoxine or Vitamin $\mathrm{B}_{6}$ is a water-soluble $\mathrm{B}$ vitamin which usually offers cofactors or prosthetic groups to different enzymatic reactions. Pyridoxine plays an important role in the metabolism of proteins, lipids, and carbohydrates. 
Besides, pyridoxine has the significant role in the function of the nervous, immune, red blood cell, and endocrine systems. It also assists to maintain the normal blood glucose level $[1,2]$. Pyridoxine (alcohol form) is usually interconverted into pyridoxal (aldehyde form) and pyridoxamine (amine form). Pyridoxine, pyridoxamine, and their phosphorylated forms are usually major forms of vitamin $\mathrm{B}_{6}$ in plant food, while pyridoxal and pyridoxal-5'phosphate (PLP) are the main forms observed in animal foods. Pyridoxine hydrochloride is the hydrochloride salt form of vitamin $\mathrm{B}_{6}$ and converted into its active coenzymatic form pyridoxal-5'-phosphate (PLP) [1-4]. Pyridoxine hydrochloride is commonly used as vitamin supplement or as a component of multivitamin preparations for the prevention and treatment of pyridoxine deficiency, sideroblastic anaemia, cardiovascular disease, Alzheimer's disease, pyridoxine-dependency seizures, metabolic disorders, pulmonary tuberculosis, hyperhomocysteinemia, cancer, anxiety, asthma, attention deficit hyperactivity disorder (ADHD), depression, dysmenorrhoea, post-partum lactation suppression, diabetes, McArdle's disease, osteoporosis, etc. [1, 4-7].

Biofield Energy is stated as quantum energy matrix that surrounds the human body resulting from the continuous movement of the electrically charged particles (ions, cells, etc.) inside the body. Biofield Energy releases constantly electromagnetic waves in the form of bio-photons from the body. Healing practitioners have the ability to harness the energy from the "universal energy field" and can transmit into any living or nonliving object(s) around the earth. The process, where the objects receive the biofield energy and respond to it in a useful way is called as Biofield Energy Healing Treatment $[8,9]$. Biofield Energy Healing therapy has been recognized as a Complementary and Alternative Medicine (CAM) health care approach by National Center of Complementary and Integrative Health (NCCIH) with other therapies, medicines and practices such as yoga, Qi Gong, Tai Chi, chiropractic/osteopathic manipulation, meditation, homeopathy, acupressure, acupuncture, healing touch, hypnotherapy, movement therapy, naturopathy, Ayurvedic medicine, traditional Chinese herbs and medicines, aromatherapy, Reiki, cranial sacral therapy, etc. [10, 11]. Biofield Energy Healing Treatment (The Trivedi Effect ${ }^{\circledR}$ ) is drawing importance in several fields include material science [12], pharmaceuticals [13], nutraceuticals [14], organic compounds [15, 16], microbiology [17], agricultural [18], biotechnology [19], genetics [20], medical [21] due to its amazing ability for modification of the characteristic properties of the numerous non-living and living substances. Scientific literature extensively reported significant problems about the bioavailability of vitamin B6. The major problems were very limited extent intestinal absorption of $\mathrm{B}_{6}$ vitamers, large rate constant of elimination due to the non-binding properties of pyridoxine to the proteins of blood plasma, and instability of pyridoxine due to the complex formation between various food, drug, and cosmetic colours, packaged or canned food stored at elevated temperatures $[1,3,4]$. The
Trivedi Effect ${ }^{\circledR}$-Energy of Consciousness Healing Treatment significantly altered physicochemical properties such as crystalline structure, crystallite size, particle size, surface area, and thermal stability through introducing a polymorph of the pharmaceutical/nutraceutical compound. It was suggested that Biofield Energy Treated pharmaceutical/nutraceutical compounds could have more bioavailable and thermally stable compared with the untreated compounds [22-26]. The physicochemical and thermal properties etc. of a pharmaceutical solid compound play an important role in drug product performance i.e. bioavailability, therapeutic efficacy, and toxicity [27, 28]. The Energy of Consciousness Healing Treatment (The Trivedi Effect $\left.{ }^{\circledR}\right)$ might modify the physicochemical and thermal properties through the possible intervention of neutrinos [29]. Thus, it was aimed to explore the impact of The Trivedi Effect ${ }^{\circledR}$ - Energy of Consciousness Healing Treatment on the physicochemical and thermal properties of pyridoxine hydrochloride using powder X-ray diffraction (PXRD), particle size analysis (PSA), differential scanning calorimetry (DSC), and thermogravimetric analysis (TGA)/ Differential thermogravimetric analysis (DTG).

\section{Materials and Methods}

\subsection{Chemicals and Reagents}

Pyridoxine Hydrochloride was purchased from Tokyo Chemical Industry Co. Ltd., Japan. All other chemicals used during the experiments were of analytical grade available in India.

\subsection{Consciousness Energy Healing Treatment Strategies}

The sample of Pyridoxine Hydrochloride was divided into two parts. One part of Pyridoxine Hydrochloride was considered as control (no Biofield Energy Treatment was provided). Consequently, the second part of Pyridoxine Hydrochloride was treated with The Trivedi Effect ${ }^{\mathbb{B}}$ - Energy of Consciousness Healing Treatment remotely under standard laboratory conditions for 3 minutes and known as The Trivedi Effect ${ }^{\mathbb{R}}$ or Biofield Energy Treated sample. This Biofield Energy Treatment was provided through the healer's unique energy transmission process by the renowned Biofield Energy Healer, Alice Branton, USA to the test item. Further, the control group was treated with "sham" healer for comparison purpose. The sham healer did not have any knowledge about the Biofield Energy Treatment. After that, the Biofield Energy Treated and untreated samples were kept in sealed conditions and characterized using PXRD, PSA, DSC, and TGA techniques.

\subsection{Characterization}

\subsubsection{Powder X-ray Diffraction (PXRD) Analysis}

The PXRD analysis of pyridoxine hydrochloride was performed on a PANalytical X'PERT3 powder X-ray diffractometer, UK. Diffraction of the analyte was carried out using a copper line as the source of radiation at the X-ray of 
the wavelength of $0.154 \mathrm{~nm}$, running at $45 \mathrm{kV}$ voltage and 40 $\mathrm{mA}$ current with a scanning rate of $18.87^{\circ} /$ second over a $2 \theta$ range of $3-50^{\circ}$. The ratio of $\mathrm{K} \alpha-2$ and $\mathrm{K} \alpha-1$ in this instrument was 0.5 ( $\mathrm{k}$, equipment constant). The data was collected in the form of a chart of the Bragg angle $(2 \theta)$ vs. intensity (counts per second), and a detailed table containing information on peak intensity counts, d value $(\AA)$, relative intensity $(\%)$, full width half maximum (FWHM) $\left({ }^{\circ} 2 \theta\right)$, area $\left(\right.$ cts $^{* \circ} 2 \theta$ ) using X'Pert data collector and X'Pert high score plus processing software. The crystallite size (G) was calculated from the Scherrer equation following the literature [22-24, 30]. The crystallite size $(\mathrm{G})$ was calculated by using the following equation 1 :

$$
\mathrm{G}=\mathrm{k} \lambda /(\mathrm{b} \operatorname{Cos} \theta)
$$

Where, $\mathrm{k}$ is the equipment constant $(0.5), \lambda$ is the $\mathrm{X}$-ray wavelength $(0.154 \mathrm{~nm})$; $\mathrm{b}$ in radians is the full-width at half of the peaks and $\theta$ the corresponding Bragg angle.

Percent change in crystallite size (G) of pyridoxine hydrochloride was calculated using following equation 2 :

$\%$ change in crystallite size $=\frac{\left[G_{\text {Treated }}-G_{\text {Control }}\right]}{G_{\text {Control }}} \times 100$

Where, $\mathrm{G}_{\text {Control }}$ and $\mathrm{G}_{\text {Treated }}$ are the crystallite size of the control and Biofield Energy Treated samples, respectively.

\subsubsection{Particle Size Analysis (PSA)}

The particle size analysis of pyridoxine hydrochloride was conducted on Malvern Mastersizer 3000, UK with a detection range between $0.01 \mu \mathrm{m}$ to $3000 \mu \mathrm{m}$ using wet method [22-24]. The sample unit (Hydro MV) was filled with a dispersant medium (Toulene) and operated the stirrer at $2500 \mathrm{rpm}$. Refractive index values for dispersant and samples were 0.0 and 1.47. The measurement was taken twice after reaching obscuration in between $10 \%$ and $20 \%$ and the average was taken of two measurements. Consequently, PSA analysis of pyridoxine hydrochloride was repeated for three times to obtain the average particle size distribution. $d_{10} \mu \mathrm{m}$, $\mathrm{d}_{50} \mu \mathrm{m}, \mathrm{d}_{90} \mu \mathrm{m}$ represent particle diameter corresponding to $10 \%, 50 \%$, and $90 \%$ of the cumulative distribution. $\mathrm{D}(4,3)$ represents the average mass-volume diameter, and SSA is the specific surface area $\left(\mathrm{m}^{2} / \mathrm{Kg}\right)$. The calculations were done by using software Mastersizer V3.50.

The percent change in particle size (d) for at below 10\% level $\left(\mathrm{d}_{10}\right), 50 \%$ level $\left(\mathrm{d}_{50}\right)$, and $90 \%$ level $\left(\mathrm{d}_{90}\right)$ was calculated using following equation 3 :

$$
\% \text { change in particle size }=\frac{\left[\mathrm{d}_{\text {Treated }}-\mathrm{d}_{\text {Control }}\right]}{\mathrm{d}_{\text {Control }}} \times 100
$$

Where, $d_{\text {Control }}$ and $d_{\text {Treated }}$ are the particle size $(\mu \mathrm{m})$ for at below $10 \%$ level $\left(\mathrm{d}_{10}\right), 50 \%$ level $\left(\mathrm{d}_{50}\right)$, and $90 \%$ level $\left(\mathrm{d}_{90}\right)$ of the control and Biofield Energy Treated samples, respectively.

Percent change in surface area (S) was calculated using following equation 4 :

$$
\% \text { change in surface area }=\frac{\left[\mathrm{S}_{\text {Treated }}-\mathrm{S}_{\text {Control }}\right]}{\mathrm{S}_{\text {Control }}} \times 100
$$

Where, $S_{\text {Control }}$ and $S_{\text {Treated }}$ are the surface area of the control and Biofield Energy Treated Pyridoxine Hydrochloride, respectively.

\subsubsection{Differential Scanning Calorimetry (DSC)}

The DSC thermogram of pyridoxine hydrochloride was achieved in a DSC Q2000 differential scanning calorimeter, USA under the dynamic nitrogen atmosphere with the flow rate of $50 \mathrm{~mL} / \mathrm{min}$ with a sample mass of $2.72 \mathrm{mg}$ using the aluminium pan at a heating rate of $10^{\circ} \mathrm{C} / \mathrm{min}$ from $30^{\circ} \mathrm{C}$ to $400^{\circ} \mathrm{C}$ [22-24]. The \% change in melting point (T) was calculated using following equation 5 :

$$
\% \text { change in melting point }=\frac{\left[\mathrm{T}_{\text {Treated }}-\mathrm{T}_{\text {Control }}\right]}{\mathrm{T}_{\text {Control }}} \times 100
$$

Where, $\mathrm{T}_{\text {Control }}$ and $\mathrm{T}_{\text {Treated }}$ are the melting point of the control and treated samples, respectively.

Percent change in the latent heat of fusion $(\Delta \mathrm{H})$ was calculated using following equation 6 :

$$
\% \text { change in latent heat of fusion }=\frac{\left[\Delta \mathrm{H}_{\text {Treated }}-\Delta \mathrm{H}_{\text {Control }}\right]}{\Delta \mathrm{H}_{\text {Control }}} \times 100
$$

Where, $\Delta \mathrm{H}_{\text {Control }}$ and $\Delta \mathrm{H}_{\text {Treated }}$ are the latent heat of fusion of the control and treated pyridoxine hydrochloride, respectively.

\subsubsection{Thermal Gravimetric Analysis (TGA) / Differential Thermogravimetric Analysis (DTG)}

TGA/DTG thermograms of Pyridoxine Hydrochloride were obtained in a TGA Q500 themoanalyzer apparatus, USA under the dynamic nitrogen atmosphere $(50 \mathrm{~mL} / \mathrm{min})$ using a platinum crucible at a heating rate of $10^{\circ} \mathrm{C} / \mathrm{min}$ from $25^{\circ} \mathrm{C}$ to $900^{\circ} \mathrm{C}$ with the recent literature [22-24]. The $\%$ change in weight loss (W) was calculated using following equation 7:

$$
\% \text { change in weight loss }=\frac{\left[\mathrm{w}_{\text {Treated }}-\mathrm{w}_{\text {Control }}\right]}{\mathrm{w}_{\text {Control }}} \times 100
$$

Where, $\mathrm{W}_{\text {Control }}$ and $\mathrm{W}_{\text {Treated }}$ are the weight loss of the control and Biofield Energy Treated pyridoxine hydrochloride, respectively.

The $\%$ change in maximum thermal degradation temperature $\left(\mathrm{T}_{\max }\right)(\mathrm{M})$ was calculated using following equation 8:

$$
\% \text { change in } \mathrm{T}_{\max }(\mathrm{M})=\frac{\left[\mathrm{M}_{\text {Treated }}-\mathrm{M}_{\text {Control }}\right]}{\mathrm{M}_{\text {Control }}} \times 100
$$

Where, $\mathrm{M}_{\text {Control }}$ and $\mathrm{M}_{\text {Treated }}$ are the $\mathrm{T}_{\max }$ values of the control and Biofield Energy Treated pyridoxine 
hydrochloride, respectively.

\section{Results and Discussion}

\subsection{Powder X-ray Diffraction (PXRD) Analysis}

The PXRD diffractograms of the control and Biofield Energy Treated pyridoxine $\mathrm{HCl}$ (Figure 1) exhibited 9 sharp and intense peaks at Bragg's angle $(2 \theta)$ equal to $10.3^{\circ}, 17.0^{\circ}$, $20.8^{\circ}, 22.0^{\circ}, 24.2^{\circ}, 25.1^{\circ}, 25.9^{\circ}, 27.9^{\circ}$, and $30.0^{\circ}$ (Table 1 ) indicating that both the samples were crystalline in nature.

The PXRD diffractogram of the control and Biofield
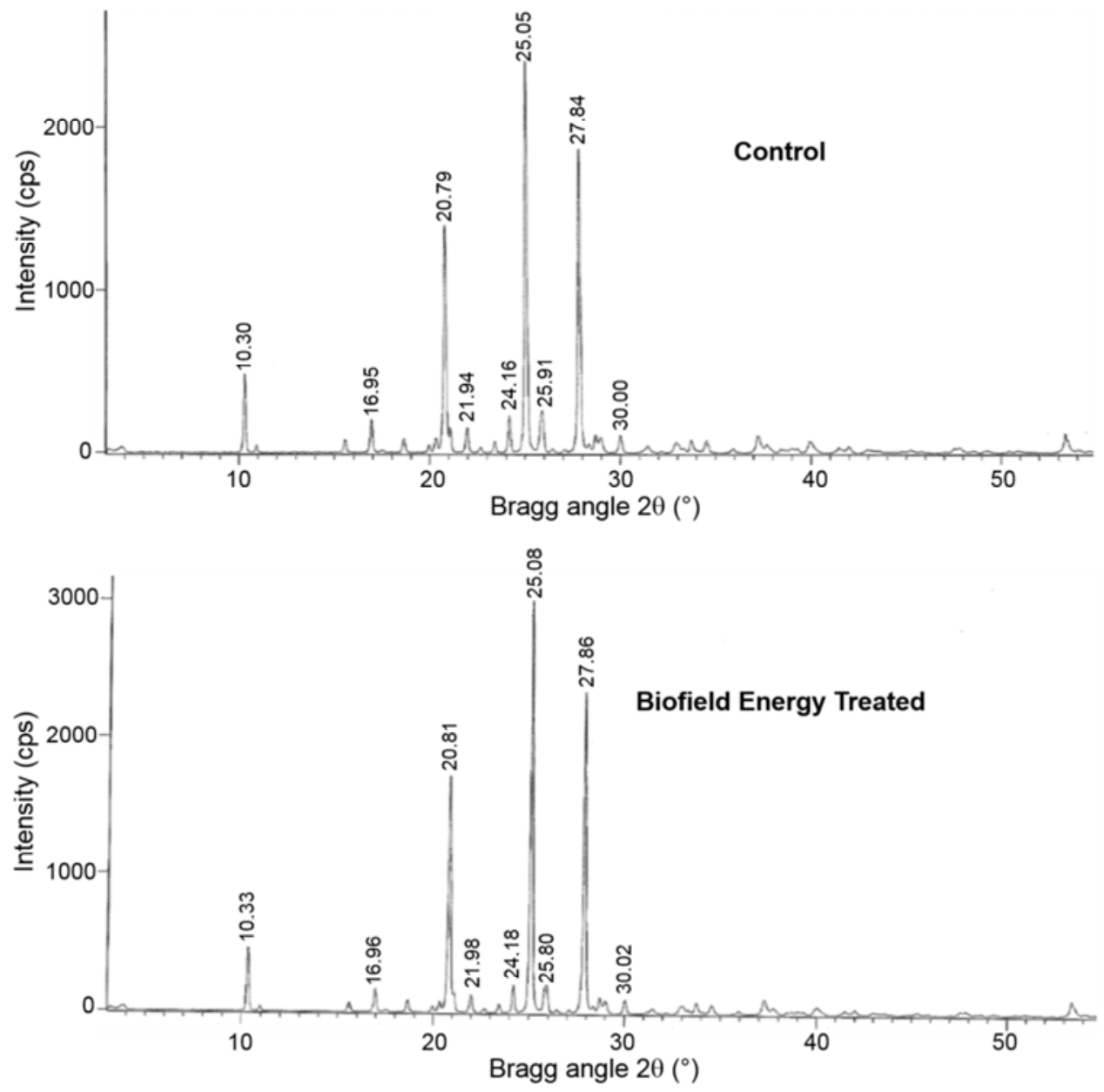

Figure 1. PXRD diffractograms of the control and Biofield Energy Treated Pyridoxine Hydrochloride.

Table 1. PXRD data for the control and Biofield Energy Treated Pyridoxine Hydrochloride.

\begin{tabular}{|c|c|c|c|c|c|c|c|}
\hline \multirow{2}{*}{ Entry No. } & \multirow{2}{*}{$\begin{array}{l}\text { Bragg } \\
\text { angle }\left({ }^{\circ} 2 \theta\right)\end{array}$} & \multicolumn{3}{|c|}{ Relative Intensity (\%) } & \multicolumn{3}{|c|}{ Crystallite size (G, nm) } \\
\hline & & Control & Treated & \% change $^{\mathrm{a}}$ & Control & Treated & $\%$ change $^{b}$ \\
\hline 1 & 10.3 & 19.93 & 15.40 & -22.73 & 38.39 & 31.41 & -18.19 \\
\hline 2 & 17.0 & 8.19 & 5.48 & -33.09 & 28.99 & 38.66 & 33.36 \\
\hline 3 & 20.8 & 58.60 & 57.67 & -1.59 & 34.99 & 34.99 & 0.00 \\
\hline 4 & 22.0 & 5.94 & 4.47 & -24.75 & 31.87 & 26.96 & -15.39 \\
\hline 5 & 24.2 & 9.04 & 6.65 & -26.44 & 31.99 & 31.99 & 0.00 \\
\hline 6 & 25.1 & 100.00 & 100.00 & 0.00 & 44.08 & 44.08 & 0.01 \\
\hline 7 & 25.9 & 10.12 & 5.62 & -44.47 & 44.15 & 44.14 & -0.02 \\
\hline 8 & 27.9 & 77.52 & 78.02 & 0.64 & 44.33 & 41.53 & -6.31 \\
\hline 9 & 30.0 & 4.36 & 3.32 & -23.85 & 50.92 & 36.52 & -28.28 \\
\hline
\end{tabular}

${ }^{a}$ denotes the percentage change in the relative intensity of Biofield Energy Treated sample with respect to the control sample; ${ }^{b}$ denotes the percentage change in the crystallite size of Biofield Energy Treated sample with respect to the control sample.
Energy Treated samples showed highest peak intensity $(100 \%)$ at $2 \theta$ equal to $25.1^{\circ}$ (Table 1 , entry 6$)$. Thereafter, the 政 significantly decreased from $1.59 \%$ to $44.47 \%$ compared to Biofield Energy Treated sample was increased by $0.64 \%$ compared to the control sample. PXRD peaks at $2 \theta$ equal to $27.9^{\circ}$ (Table 1 , entry 8 ) in the 
The crystallite sizes of the Biofield Energy Treated sample at $2 \theta$ equal to $10.3^{\circ}, 22.0^{\circ}, 27.9^{\circ}$, and $30.0^{\circ}$ (Table 1 , entry 1 , 4 , 8, and 9) were significantly decreased from $6.31 \%$ to $28.28 \%$ with respect to the control sample. Additionally, at position $2 \theta$ equal to $17.0^{\circ}$ (Table 1 , entry 2 ), the crystallite size of the Biofield Energy Treated sample was significantly increased by $33.36 \%$ compared with the control sample. Consequently, the crystallite sizes of the control and Biofield Energy Treated pyridoxine $\mathrm{HCl}$ at $2 \theta$ equal to $20.8^{\circ}, 24.2^{\circ}$, $25.1^{\circ}$, and $25.9^{\circ}$ (Table 1 , entry $3,5,6$, and 7) remained unaltered. Overall, the average crystallite size of the Biofield Energy Treated sample $(38.86 \mathrm{~nm})$ was significantly reduced by $5.55 \%$ compared with the control sample $(36.70 \mathrm{~nm})$. This result indicated that crystallinity of the Biofield Energy Treated pyridoxine hydrochloride was significantly reduced compared with the control sample. Scientific literature reported that Biofield Energy Treatment has the significant capability to produce a new polymorph by altering the crystal morphology of the pharmaceuticals and nutraceuticals through changing the relative intensities and crystallite size of the characteristic diffraction face [22-24, 31]. The significant variations in the crystallite size and relative intensities indicated the modification of the crystal morphology of the Biofield Energy Treated pyridoxine hydrochloride compared to the control sample. The Trivedi Effect $^{\circledR}$ - Energy of Consciousness Healing Treatment probably led to produce a polymorphic form through the energy transferred into the pyridoxine hydrochloride. Zhao et al. reported that decreased intensity of characteristic diffraction peaks and reduced crystallinity increased the dissolution rate of an orally administered pharmaceutical powder [32]. Thus, it can be anticipated that The Trivedi Effect $^{\circledR}$ might offer better bioavailability of pyridoxine hydrochloride in its oral formulation.

\subsection{Particle Size Analysis (PSA)}

The particle size of both the control and Biofield Energy Treated pyridoxine hydrochloride was assessed and is shown in Table 2.

Table 2. Particle size distribution of the control and Biofield Energy Treated Pyridoxine Hydrochloride.

\begin{tabular}{lllll}
\hline Parameter & $\mathbf{d}_{\mathbf{1 0}}(\boldsymbol{\mu m})$ & $\mathbf{d}_{\mathbf{5 0}}(\boldsymbol{\mu m})$ & $\mathbf{d}_{\mathbf{9 0}}(\boldsymbol{\mu m})$ & $\mathbf{D}(\mathbf{4}, \mathbf{3})(\boldsymbol{\mu m})$ \\
\hline Control & 10.89 & 32.56 & 111.40 & 48.11 \\
Biofield Treated $_{\text {Percent change }}^{*}(\%)$ & 9.38 & 29.32 & 102.63 & 44.94 \\
\hline
\end{tabular}

$\mathrm{d}_{10}, \mathrm{~d}_{50}$, and $\mathrm{d}_{90}$ : particle diameter corresponding to $10 \%, 50 \%$, and $90 \%$ of the cumulative distribution; D( 4,3$)$ : the average mass-volume diameter; SSA: the specific surface area; ${ }^{*}$ denotes the percentage change in the Particle size distribution of the Biofield Energy Treated sample with respect to the control sample.

The particle size distribution of the control pyridoxine $\mathrm{HCl}$ was found at $\mathrm{d}_{10}=10.89 \mu \mathrm{m}, \mathrm{d}_{50}=32.56 \mu \mathrm{m}, \mathrm{d}_{90}=111.40$ $\mu \mathrm{m}$, and $\mathrm{D}(4,3)=48.11 \mu \mathrm{m}$. Subsequently, the particle size distribution of the Biofield Energy Treated sample was observed at $\mathrm{d}_{10}=9.38 \mu \mathrm{m}, \mathrm{d}_{50}=29.32 \mu \mathrm{m}, \mathrm{d}_{90}=102.63 \mu \mathrm{m}$, and $\mathrm{D}(4,3)=44.94 \mu \mathrm{m}$. The particle size values at $\mathrm{d}_{10}, \mathrm{~d}_{50}$, $\mathrm{d}_{90}$, and $\mathrm{D}(4,3)$ in Alice's Biofield Energy Treated sample were significantly decreased by $13.87 \%, 9.95 \%, 7.87 \%$, and $6.59 \%$, respectively compared to the control sample. The specific surface area of Biofield Energy Treated pyridoxine hydrochloride $\left(276.00 \mathrm{~m}^{2} / \mathrm{Kg}\right)$ was significantly increased by $13.67 \%$ compared with the control sample $\left(242.80 \mathrm{~m}^{2} / \mathrm{Kg}\right)$. It is assumed that The Trivedi Effect ${ }^{\circledR}$ might act as an external force like ball milling for reducing the particle size of pyridoxine $\mathrm{HCl}$. The literature reported that a pharmaceutical solid compound having reduced particle size and crystallinity with the increased surface area possesses improved solubility dissolution rate, and finally bioavailability [32-34]. Thus, it is anticipated that The Trivedi Effect $^{\circledR}$ - Energy of Consciousness Healing Treated pyridoxine hydrochloride might offer better bioavailability than the untreated sample.

\subsection{Differential Scanning Calorimetry (DSC) Analysis}

DSC has been found as a simple technique to characterize the thermal behaviors like melting and crystallization behaviors [32]. The DSC thermogram of the control pyridoxine hydrochloride (Figure 2) showed only a sharp endothermic peak at $214.14^{\circ} \mathrm{C}$ which is the melting point of pyridoxine hydrochloride. The melting point of the Biofield Energy Treated sample $\left(213.82^{\circ} \mathrm{C}\right)$ was slightly reduced by $0.20 \%$ compared as the control sample (Table 3 ).

Table 3. DSC data for both control and Biofield Energy Treated samples of Pyridoxine Hydrochloride.

\begin{tabular}{|c|c|c|c|c|}
\hline \multirow{2}{*}{ Sample } & \multicolumn{3}{|c|}{ Melting point $\left({ }^{\circ} \mathrm{C}\right)$} & \multirow{2}{*}{$\Delta \mathbf{H}(\mathbf{J} / \mathbf{g})$} \\
\hline & $\mathbf{T}_{\text {onset }}$ & $\mathbf{T}_{\text {peak }}$ & $\mathbf{T}_{\text {endset }}$ & \\
\hline Control Sample & 214.50 & 214.24 & 217.59 & 208.80 \\
\hline Biofield Energy Treated & 213.35 & 213.82 & 215.16 & 157.60 \\
\hline$\%$ Change* & -0.54 & -0.20 & -1.12 & -24.52 \\
\hline
\end{tabular}

$\mathrm{T}_{\text {onset }}$ : Onset melting temperature, $\mathrm{T}_{\text {peak }}$ : Peak melting temperature, $\mathrm{T}_{\text {endset }}$ : Endset melting temperature, $\Delta \mathrm{H}$ : Latent heat of fusion, ${ }^{*}$ denotes the percentage change of the Biofield Energy Treated sample with respect to the control sample.

The latent heat of fusion $(\Delta \mathrm{H})$ of the Biofield Energy Treated pyridoxine hydrochloride was significantly decreased by $24.52 \%$ compared with the control sample (Table 3 ). The reduction in the latent heat of fusion can be attributed to the disrupted molecule chains and reduced the crystallization structure [32]. Thus, it is assumed that Alice's Biofield 
Energy treatment may be responsible for the disruption the molecular chains and crystallization structure of pyridoxine hydrochloride. The results suggested that the thermal stability of the Biofield Energy Treated sample was decreased compared with the control sample.
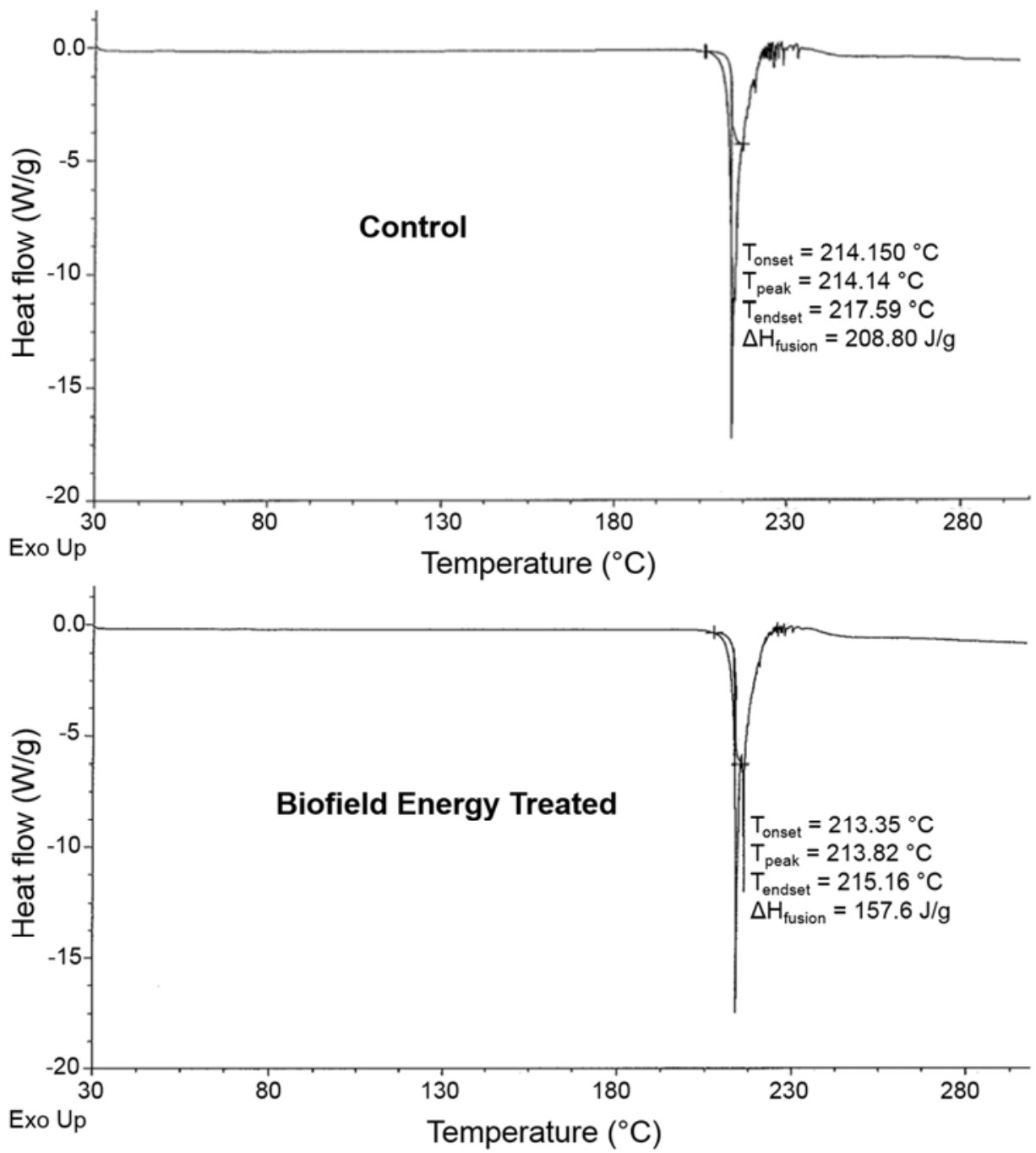

Figure 2. DSC thermograms of the control and Biofield Energy Treated Pyridoxine Hydrochloride.

\subsection{Thermal Gravimetric Analysis (TGA) / Differential Thermogravimetric Analysis (DTG)}

Literature mentioned that pyridoxine hydrochloride was stable below $150^{\circ} \mathrm{C}[35,36]$. The TGA thermograms of the control and Biofield Energy Treated samples displayed two steps of thermal degradation (Figure 3). The percentage weight loss in Biofield Energy Treated pyridoxine hydrochloride was increased by $3.58 \%$ in the $1^{\text {st }}$ step of degradation, while the percentage weight loss in the $2^{\text {nd }}$ step degradation was reduced by $1.23 \%$ compared with the control sample (Table 4). The total weight loss in the Biofield Energy Treated pyridoxine hydrochloride was increased by $1.76 \%$ compared to the control sample (Table 4).

Table 4. TGA/DTG data of the control and Biofield Energy Treated samples of Pyridoxine Hydrochloride.

\begin{tabular}{|c|c|c|c|c|}
\hline \multirow{2}{*}{ Sample } & \multicolumn{3}{|c|}{ TGA Weight loss (\%) } & \multirow{2}{*}{$\mathbf{T}_{\max }\left({ }^{\circ} \mathbf{C}\right)$} \\
\hline & $1^{\text {st }}$ step & $2^{\text {nd }}$ step & Total & \\
\hline Control Sample & 20.10 & 12.23 & 32.33 & 213.16 \\
\hline Biofield Energy Treated Sample & 20.82 & 12.08 & 32.90 & 211.28 \\
\hline$\%$ Change $^{*}$ & 3.58 & -1.23 & 1.76 & -0.88 \\
\hline
\end{tabular}

*denotes the percentage change of the Biofield Energy Treated sample with respect to the control sample, $\mathrm{T}_{\max }=$ the temperature at which maximum weight loss takes place in TG or peak temperature in DTA. 

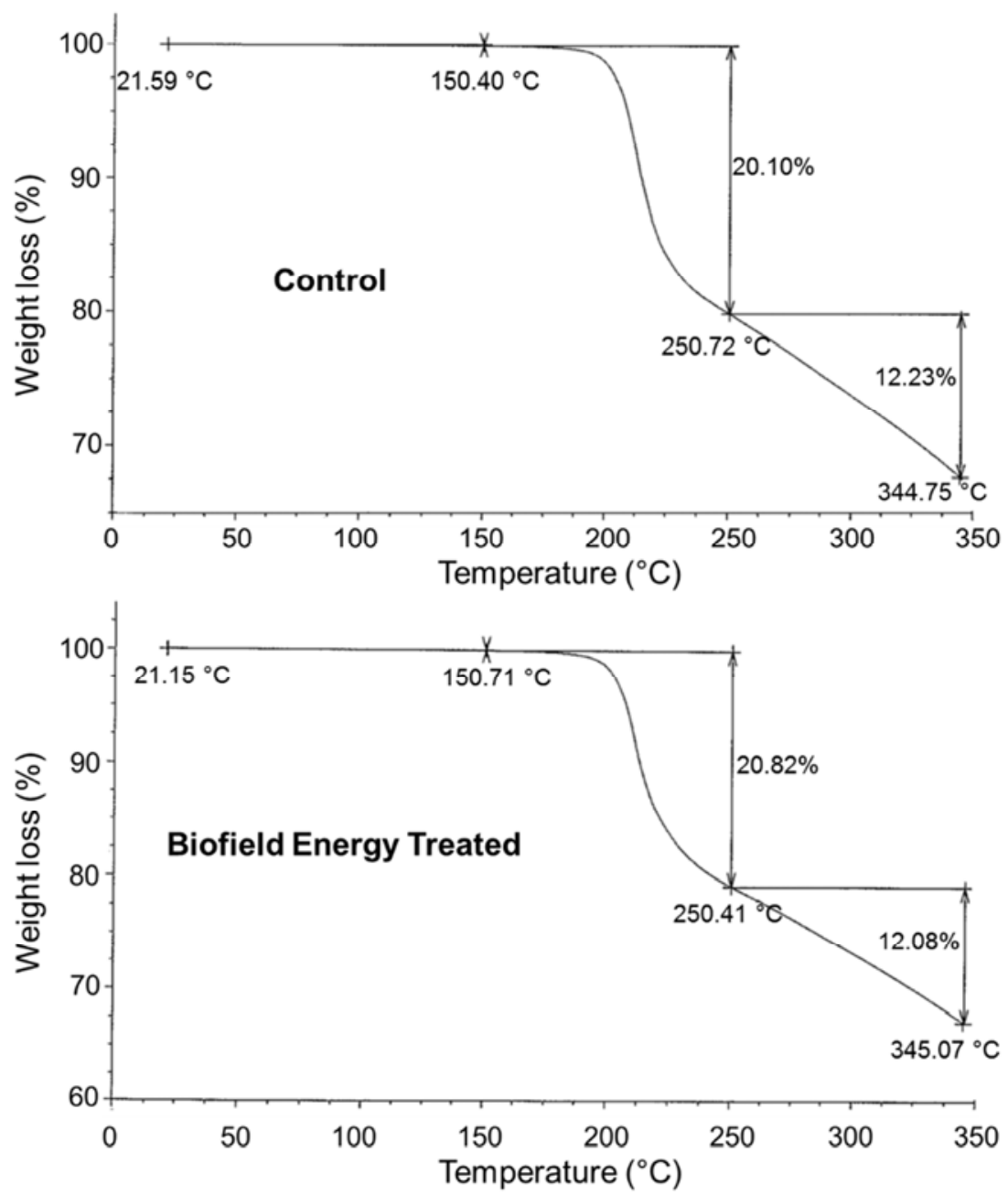

Figure 3. TGA thermograms of the control and Biofield Energy Treated Pyridoxine Hydrochloride.

The DTG thermograms of the control and Biofield Energy Treated samples (Figure 4) exhibited only one peak. The control sample was thermally stable up to $213.16^{\circ} \mathrm{C}$, while Biofield Energy Treated sample was stable up to $211.28^{\circ} \mathrm{C}$. The $\mathrm{T}_{\max }$ of the Biofield Energy Treated sample was lower by
$0.88 \%$ than the control sample as shown in Table 4. Overall, TGA/DTG revealed that the thermal stability of the Biofield Energy Treated pyridoxine hydrochloride was reduced compared with the control sample.

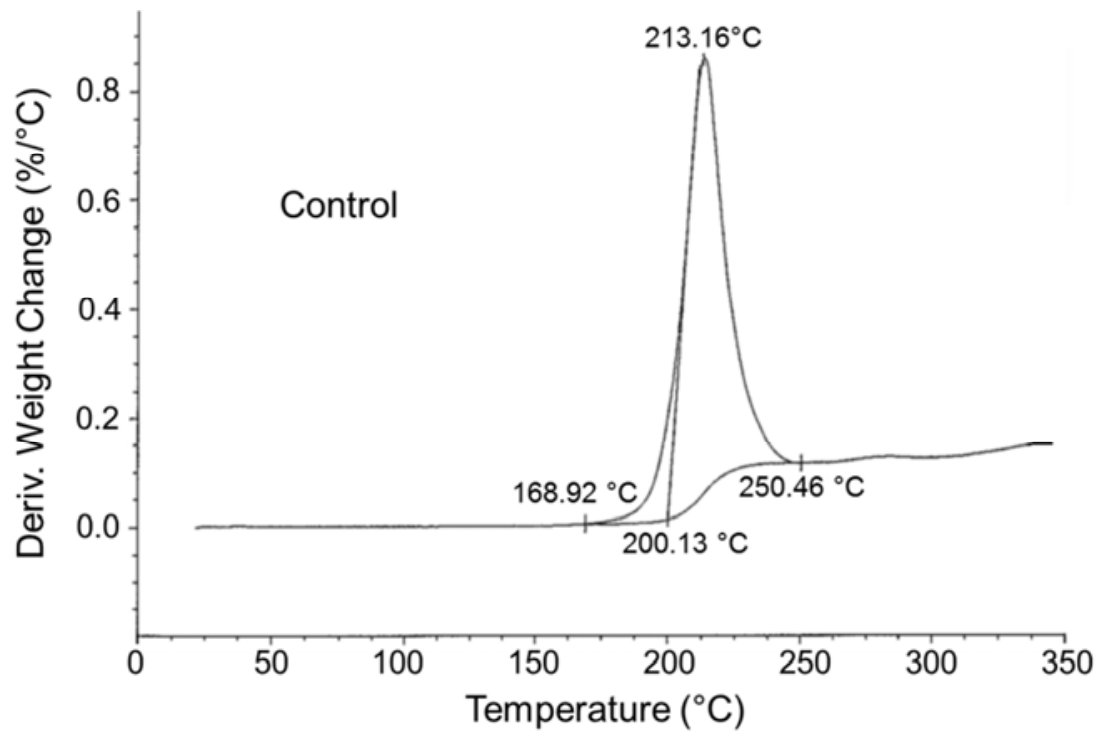




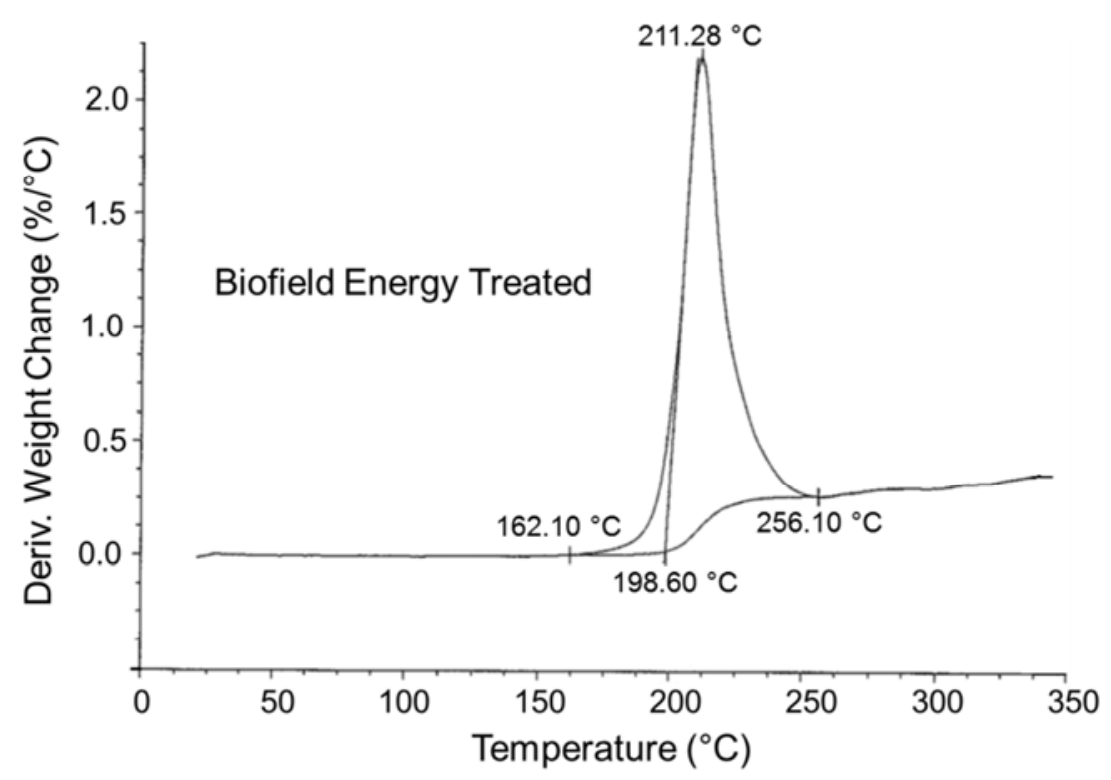

Figure 4. DTG thermograms of the control and Biofield Energy Treated Pyridoxine Hydrochloride.

\section{Conclusions}

The Trivedi Effect ${ }^{\circledR}$ - Energy of Consciousness Healing Treatment displayed significant effects on the relative intensities and crystallite size of the most characteristics diffraction peaks, particle size, surface area, and thermal stability of pyridoxine hydrochloride or vitamin $\mathrm{B}_{6}$. The relative intensities of the most characteristic diffraction peaks in the Alice's Biofield Energy Treated pyridoxine hydrochloride were significantly decreased from $1.59 \%$ to $44.47 \%$, only one peak's intensity was increased by $0.64 \%$ compared with the control sample. The crystallite size of the most characteristic diffraction peak in the treated sample was reduced from $6.31 \%$ to $28.28 \%$, while only one peak's crystallite size was increased by $33.36 \%$ compared with the control sample. Overall, the average crystallite size of the treated sample was significantly decreased by $5.55 \%$ compared with the control sample. The particle size values at $\mathrm{d}_{10}, \mathrm{~d}_{50}, \mathrm{~d}_{90}$, and $\mathrm{D}(4,3)$ in Biofield Energy Treated sample were significantly decreased by $13.87 \%, 9.95 \%, 7.87 \%$, and $6.59 \%$, respectively compared with the control sample. The specific surface area of the Biofield Energy Treated sample was significantly increased by $13.67 \%$ compared to the control sample. The DSC analysis showed that the melting point of the treated sample was decreased by $0.20 \%$ with a significant reduction of the latent heat of fusion by $24.52 \%$ compared to the control sample. The TGA analysis revealed that the total weight loss in the treated sample was increased by $1.76 \%$ compared with the control sample. The DTG analysis indicated that the $\mathrm{T}_{\max }$ of the treated sample was decreased by $0.88 \%$ compared with the control sample. Overall, the thermal analysis indicated that the thermal stability of the treated pyridoxine hydrochloride was decreased compared to the control sample. Thus, The Trivedi Effect $^{\circledR}$ might lead to produce a polymorphic form of pyridoxine hydrochloride which would be more soluble, absorbable, have a higher dissolution rate and be more bioavailable compared with the untreated sample. The Biofield Energy Treated pyridoxine hydrochloride would be useful to design better nutraceutical and pharmaceutical formulations which might afford better therapeutic response against pyridoxine deficiency, hereditary sideroblastic anemia, premenstrual syndrome, cardiovascular disease, Alzheimer's disease, pyridoxine-dependency seizures, metabolic disorders, pulmonary tuberculosis, hyperhomocysteinemia, cancer, anxiety, asthma, attention deficit hyperactivity disorder (ADHD), depression, dysmenorrhea, akathisia, angioplasty, birth outcomes, carpal tunnel syndrome, cognitive function, hyperkinetic cerebral dysfunction syndrome, hypertension, immune system function, lactation suppression, McArdle's disease, osteoporosis, breast pain, pregnancy-induced nausea and vomiting, Tardive dyskinesia, febrile seizures, autism, stroke recurrence, etc.

\section{Acknowledgements}

The authors are grateful to GVK Biosciences Pvt. Ltd., Trivedi Science, Trivedi Global, Inc., Trivedi Testimonials, and Trivedi Master Wellness for their assistance and support during this work.

\section{References}

[1] Dakshinamurti S, Dakshinamurti K (2007) Vitamin $B_{6}$ in Handbook of Vitamins, $4^{\text {th }}$ Edn., Zempleni J, Rucker RB, McCormick DB, Suttie JW, CRC Press, Taylor \& Francis Group, Boca Raton, USA, pp. 315-360.

[2] https://en.wikipedia.org/wiki/Pyridoxine (access on 13.05.2017). 
[3] Aboul-Enein HY, Loutfy MA (1984) Pyridoxine Hydrochloride in Analytical Profiles of Drug Substances, Florey K (Ed.), Vol 13, Academic Press, Inc., Orlando, USA, pp. 448-478.

[4] Leklem JE (2001) Vitamin B $_{6}$ in Handbook of Vitamins, $3^{\text {rd }}$ Edn., Rucker RB, Suttie JW, McCormick DB, Machlin LJ, Marcel Dekker, Inc., New York, pp. 339-396.

[5] http://www.naturalmedicinejournal.com/journal/201109/many-uses-vitamin-b6 (access on 15.02.2017)

[6] Qian B, Shen S, Zhang J, Jing P (2017) Effects of Vitamin $B_{6}$ Deficiency on the Composition and Functional Potential of $\mathrm{T}$ Cell Populations. J Immunol Res 2017: 2197975.

[7] AlSaad D, Awaisu A, Elsalem S, Abdulrouf PV, Thomas B, AlHail M. Is pyridoxine effective and safe for post-partum lactation inhibition? A systematic review. J Clin Pharm Ther. 2017 Apr 19. doi: $10.1111 /$ jept.12526.

[8] http://www.redspiritenergyhealing.com/humanbiofield.html (accessed 10.09.2016).

[9] Nemeth L (2008) Energy and biofield therapies in practice. Beginnings 28: 4-5.

[10] Koithan M (2009) Introducing complementary and alternative therapies. J Nurse Pract 5: 18-20.

[11] Trivedi MK, Branton A, Trivedi D, Nayak G, Nykvist CD, Lavelle C, Przybylski DP, Vincent DH, Felger D, Konersman DJ, Feeney EA, Prague JA, Starodub JL, Rasdan K, Strassman KM, Soboleff L, Mayne MA, Keesee MM, Pillai PN, Ansley PC, Schmitz RD, Sodomora SM, Sethi KK, Panda P, Jana S (2017) Evaluation of the physicochemical, spectral, and thermal properties of sodium selenate treated with the Energy of Consciousness (The Trivedi Effect ${ }^{\mathbb{B}}$ ). Advances in Bioscience and Bioengineering 5: 12-21.

[12] Trivedi MK, Tallapragada RM, Branton A, Trivedi D, Nayak G, Latiyal O, Jana S (2015) Evaluation of physical and structural properties of biofield energy treated barium calcium tungsten oxide. Advances in Materials 4: 95-100.

[13] Trivedi MK, Patil S, Shettigar H, Singh R, Jana S (2015) An impact of biofield treatment on spectroscopic characterization of pharmaceutical compounds. Mod Chem Appl 3: 159.

[14] Trivedi MK, Tallapragada RM, Branton A, Trivedi D, Nayak G, Latiyal O, Jana S (2015) Potential impact of biofield treatment on atomic and physical characteristics of magnesium. Vitam Miner 3: 129.

[15] Trivedi MK, Branton A, Trivedi D, Nayak G, Singh R, Jana S (2015) Characterization of physical, thermal and spectroscopic properties of biofield energy treated $p$-phenylenediamine and p-toluidine. J Environ Anal Toxicol 5: 329.

[16] Trivedi MK, Branton A, Trivedi D, Nayak G, Singh R, Jana S (2015) Characterization of biofield energy treated 3chloronitrobenzene: Physical, thermal, and spectroscopic studies. J Waste Resources 5: 183.

[17] Trivedi MK, Branton A, Trivedi D, Nayak G, Mondal SC, Jana S (2015) Antimicrobial sensitivity, biochemical characteristics and biotyping of Staphylococcus saprophyticus: An impact of biofield energy treatment. J Women's Health Care 4: 271.

[18] Trivedi MK, Branton A, Trivedi D, Nayak G, Gangwar M,
Jana S (2015) Agronomic characteristics, growth analysis, and yield response of biofield treated mustard, cowpea, horse gram, and groundnuts. International Journal of Genetics and Genomics 3: 74-80.

[19] Trivedi MK, Branton A, Trivedi D, Nayak G, Bairwa K, Jana S (2015) Characterization of physicochemical and spectroscopic properties of biofield energy treated bio peptone. Advances in Bioscience and Bioengineering 3: 59-66.

[20] Trivedi MK, Branton A, Trivedi D, Nayak G, Gangwar M, Jana S (2015) Antibiogram and genotypic analysis using 16S rDNA after biofield treatment on Morganella morganii. Adv Tech Biol Med 3: 137.

[21] Trivedi MK, Patil S, Shettigar H, Mondal SC, Jana S (2015) The potential impact of biofield treatment on human brain tumor cells: A time-lapse video microscopy. J Integr Oncol 4: 141.

[22] Trivedi MK, Branton A, Trivedi D, Nayak G, Plikerd WD, Surguy PL, Kock RJ, Piedad RB, Callas RP, Ansari SA, Barrett SL, Friedman S, Christie SL, Chen Liu S-M, Starling SE, Jones S, Allen SM, Wasmus SK, Benczik TA, Slade TC, Orban T, Vannes VL, Schlosser VM, Albino YSY, Sethi KK, Panda P, Jana S (2017) Evaluation of the physicochemical, spectral, thermal and behavioral properties of sodium selenate: influence of the energy of consciousness healing treatment. American Journal of Quantum Chemistry and Molecular Spectroscopy 2: 18-27.

[23] Trivedi MK, Branton A, Trivedi D, Nayak G, Wellborn BD, Smith DL, Koster DA, Patric E, Singh J, Vagt KS, Callas KJ, Panda P, Sethi KK, Jana S (2017) Characterization of physical, structural, thermal, and behavioral properties of the consciousness healing treated zinc chloride. World Journal of Applied Chemistry 2: 57-66.

[24] Trivedi MK, Branton A, Trivedi D, Nayak G, Lee AC, Hancharuk A, Sand CM, Schnitzer DJ, Thanasi R, Meagher EM, Pyka FA, Gerber GR, Stromsnas JC, Shapiro JM, Streicher LN, Hachfeld LM, Hornung MC, Rowe PM, Henderson SJ, Benson SM, Holmlund ST, Salters SP, Panda P, Jana S (2017) Evaluation of the impact of biofield energy healing treatment (The Trivedi Effect ${ }^{\mathbb{B}}$ ) on the physicochemical, thermal, structural, and behavioral properties of magnesium gluconate. International Journal of Nutrition and Food Sciences. 6: 71-82.

[25] Trivedi MK, Branton A, Trivedi D, Nayak G, Balmer AJ, Anagnos D, Kinney JP, Holling JM, Balmer JA, Duprey-Reed LA, Parulkar VR, Panda P, Sethi KK, Jana S (2017) Evaluation of the Energy of Consciousness Healing Treated Withania Somnifera (Ashwagandha) Root Extract Using LCMS, GC-MS, and NMR Spectroscopy, American Journal of Biomedical and Life Sciences 5(2), 16-25.

[26] Trivedi MK, Branton A, Trivedi D, Nayak G, Lee AC, Hancharuk A, Sand CM, Schnitzer DJ, Thanasi R, Meagher EM, Pyka FA, Gerber GR, Stromsnas JC, Shapiro JM, Streicher LN, Hachfeld LM, Hornung MC, Rowe PM, Henderson SJ, Benson SM, Holmlund ST, Salters SP, Panda P, Jana $S$ (2017) A comprehensive analytical evaluation of the Trivedi Effect ${ }^{\circledR}$ - Energy of Consciousness Healing Treatment on the physical, structural, and thermal properties of zinc chloride. American Journal of Applied Chemistry. 5: 7-18.

[27] Gupta KR, Askarkar SS, Joshi RR, Padole YF (2015) Solid state properties: Preparation and characterization. Der Pharmacia Sinica 6: 45-64. 
[28] Storey RA, Ymen I (2011) Solid state characterization of Pharmaceuticals, Wiley-Blackwell, UK.

[29] Trivedi MK, Mohan TRR (2016) Biofield energy signals, energy transmission and neutrinos. American Journal of Modern Physics 5: 172-176.

[30] Langford JI, Wilson AJC (1978) Scherrer after sixty years: A survey and some new results in the determination of crystallite size. J Appl Cryst 11: 102-113.

[31] Raza K, Kumar P, Ratan S, Malik R, Arora S (2014) Polymorphism: The phenomenon affecting the performance of drugs. SOJ Pharm Pharm Sci 1: 10.

[32] Zhao Z, Xie M, Li Y, Chen A, Li G, Zhang J, Hu H, Wang X, Li S (2015) Formation of curcumin nanoparticles via solutionenhanced dispersion by supercritical $\mathrm{CO}_{2}$. Int $\mathrm{J}$ Nanomedicine 10: 3171-3181.
[33] Chereson R (2009) Bioavailability, bioequivalence, and drug selection. In: Makoid CM, Vuchetich PJ, Banakar UV (Eds) Basic pharmacokinetics $\left(1^{\text {st }}\right.$ Edn $)$ Pharmaceutical Press, London.

[34] Mosharrof M, Nyström C (1995) The effect of particle size and shape on the surface specific dissolution rate of microsized practically insoluble drugs. Int J Pharm 122: 3547.

[35] Juhasz M, Kitahara Y, Takahashi S, Fujii T (2012) Study of the Thermal Stability Properties of Pyridoxine Using Thermogravimetric Analysis. Analytical Letters 45: 15191525 .

[36] http://www.hino.meiseiu.ac.jp/chem/fujii/CEEC Poster/poster $\% 20(\mathrm{JM}) \% 20$ to\%20CEEC-TAC1.pdf (access on 15.05.2017) 